\title{
Effects of canola meal pellet conditioning temperature and time on ruminal and intestinal digestion, hourly effective degradation ratio, and potential nitrogen to energy synchronization in dairy cows
}

\author{
Xuewei Huang, ${ }^{*}$ Nazir A. Khan, ${ }^{*} \dagger$ Xuewei Zhang, ${ }^{*} \ddagger$ and Peiqiang $\mathrm{Yu}^{*} \ddagger^{1}$ \\ *Ministry of Agriculture Strategic Feed Research Division, Department of Animal and Poultry Science, College of Agriculture and Bioresources, \\ University of Saskatchewan, Saskatoon, SK, S7N 5A8, Canada \\ †Department of Animal Nutrition, The University of Agriculture Peshawar, 25130, Pakistan \\ $\ddagger$ College of Animal Science and Veterinary Medicine, Tianjin Agricultural University, 300384 Tianjin, China
}

\begin{abstract}
The increase in bio-oil production in North America has resulted in millions of tonnes of co-products: canola meal and carinata meal. Little research has been conducted to determine the effect of pellet conditioning temperature, time, and their interaction on processinginduced changes in nutrient digestibility in the rumen and intestine (in vitro) of dairy cattle. The objectives of this study were to investigate the effects of conditioning temperature $\left(70,80\right.$, and $\left.90^{\circ} \mathrm{C}\right)$, time $(50$ and 75 $\mathrm{s})$, and their interaction (temperature $\times$ time) during the pelleting of canola meal on (1) rumen degradation kinetics and effective rumen degradability of dry matter, crude protein (CP), and neutral detergent fiber; (2) intestinal digestibility of rumen-undegradable protein (RUP); and (3) hourly effective rumen degradation ratio and potential $\mathrm{N}$ to energy synchronization in dairy cattle. The results showed that the temperature and duration of pellet conditioning significantly altered the degradation characteristics of nutrients in the rumen. Pelleting increased CP degradation in the rumen, and $\mathrm{CP}$ digestion site was shifted to the rumen rather than to the small intestine. When conditioning temperature was set $80^{\circ} \mathrm{C}$, the rumen degradation of $\mathrm{CP}$ and neutral detergent fiber was highest, but postrumen digestion was lowest. With respect to intestinal digestion, the available $\mathrm{CP}$ for intestinal digestion became less because of reduced RUP supply to the small intestine. The pelleting process tended to significantly affect the intestinal digestibility of RUP. However, the total digestible CP content of canola meal was not affected. In conclusion, pelleting induced changes in rumen and intestinal digestion profiles, and altered the potential $\mathrm{N}$ to energy synchronization and hourly effective rumen degradation ratio of canola meal in dairy cattle.
\end{abstract}

Received December 30, 2014.

Accepted August 3, 2015.

${ }^{1}$ Corresponding author: Peiqiang.yu@usask.ca
Key words: pelleting canola meal, ruminal and intestinal digestion of nutrients, hourly effective degradation ratio, nitrogen to energy synchronization

\section{INTRODUCTION}

The production of Canadian canola was over 15 million tonnes in 2013 (Canola Council of Canada, 2013). Canola meal, a co-product from bio-oil extraction processing of canola seed, has high CP content and premium protein quality because it contains low concentrations $(<30 \mu \mathrm{mol})$ of antinutritional compounds called glucosinolates (Theodoridou and Yu, 2013). Therefore canola meal is used in both monogastric and ruminant diets (Newkirk, 2009a,b) and together with rapeseed meal is the second most traded protein source in the global animal feed market (Newkirk, 2009a,b; Heendeniya et al., 2012). To further improve the competitiveness of canola meal in the feed market, it is necessary to develop suitable canola meal-based pelleted products with an improved or undamaged nutrient quality, and high transportation efficiency and durability.

Although the nutritional values of canola meal for dairy cows have been extensively studied (Heendeniya et al., 2012; Theodoridou and Yu, 2013), information about the effects of conditioning temperature and time during the pelleting on the nutritional value of processed meal is insufficient. Specifically, the digestible NDF in canola meal is an important factor contributing to the energy content of canola meal; however, little attention has been paid to the effect of different processing conditions on NDF availability of canola meal. Pelleting has been widely used in the animal feed industry and proved advantageous in improving protein digestibility of both single feed ingredients and compound feeds (Thomas and van der Poel, 1996; Thomas et al., 1997; Abdollahi et al., 2013). Van der Poel et al. (1995) and Goelema et al. (1999) reported that degradation and passage rates of feeds through animals' digestive system can be altered by feed processing methods. Pelleting improved 
rumen degradation of resistant starch by $15 \%$ (Tamminga and Goelema, 1995; Thomas and van der Poel, 1996) and also improved CP degradation in the rumen of dairy cattle (Goelema et al., 1999). However, the effects of the pelleting process on feed materials should take into consideration the interrelations between conditioning, pelleting, and cooling (Thomas et al., 1997).

Understanding how rumen degradation kinetics and intestinal digestion characteristics, and nutrient supply to dairy cattle, are affected by pellet processing conditions is vital for feed evaluation. Hence, it is of great interest to investigate the effects of pelleting under different conditioning temperatures and time on nutrient profiles and digestion characteristics of canola meal to find the optimal processing conditions. In the previous study (Huang et al., 2015), we reported the effects of conditioning temperature and time during the pelleting process of canola meal on processing-induced changes in protein molecular structure, pellet durability index, detailed chemical profile, $\mathrm{CP}$ and carbohydrate subfractions, total digestible nutrients, and energy values. The objectives of this second study were to investigate the effects of conditioning temperature $\left(70,80\right.$, and $\left.90^{\circ} \mathrm{C}\right)$, time (50 and $75 \mathrm{~s}$ ), and their interaction (temperature $\times$ time) during the pelleting process of canola meal on (1) rumen degradation kinetics and rumen availability of DM, total carbohydrates (CHO), CP, and NDF; (2) intestinal digestibility (in vitro) of RUP; and (3) hourly effective rumen degradation ratio and potential $\mathrm{N}$ to energy synchronization in dairy cattle.

\section{MATERIALS AND METHODS}

\section{Pelleting-Process}

Information on canola meal and the procedure of pelleting process is reported in the previous manuscript (Huang et al., 2015). Briefly, 2 representative sources of the meal were obtained from a commercial feed company (Federated Cooperatives Ltd., Saskatoon, SK, Canada) with different manufacturing dates. A California laboratory pellet mill (California Pellet Mill Co., Crawfordsville, IN) was used to produce canola meal pellets at 3 different conditioning temperatures $\left(70,80\right.$, and $\left.90^{\circ} \mathrm{C}\right)$ arranged in a factorial combination with 2 different conditioning time (50 and $75 \mathrm{~s}$ ), resulting in a total of 6 treatment samples (3 temperatures $\times 2$ time $)$ for each batch $(\mathrm{n}=2)$ of canola meal. Steam conditioning was used before meal mash went through the pelleting die. Pellets were exposed in the air for 24 $\mathrm{h}$ to cool pellets before the pellet durability test. The detailed chemical profile and changes in pellet durability index during the different pellet processing were re- ported earlier (Huang et al., 2015; Supplemental Table S1; http://dx.doi.org/10.3168/jds.2014-9295).

\section{Animal, Diets, and Rumen Incubation}

Five nonlactating Holstein cows were used in the in situ trial to evaluate degradation characteristics of canola meal pellets processed under different conditions. Each cow was fitted with a rumen cannula with an internal diameter of $10 \mathrm{~cm}$ (Bar Diamond, Parma, ID). The cows were fed a TMR twice daily at 0800 and $1600 \mathrm{~h}$ with water available ad libitum. The TMR was formulated (on DM basis) with $56.1 \%$ barley silage, $14.3 \%$ chopped alfalfa, and $29.6 \%$ concentrate (containing barley, wheat, oats, canola meal, soybean meal, wheat DDGS, corn gluten meal, molasses, golden flakes, canola oil, minerals, and vitamins) to meet the nutrient requirement according to NRC (2001). The detailed diet information was reported previously (Nuez-Ortín and Yu, 2010). The animals were cared for under the guidance of the Canadian Council on Animal Care (CCAC, 1993) and the experiments were approved by Animal Research Ethics Board (AREB) at the University of Saskatchewan, Canada with Animal Use Approval Protocol \#19910012.

The in situ method was used to conduct 2 experimental runs for the rumen incubation (Ørskov and McDonald, 1979; Tamminga et al., 1994). Around $7 \mathrm{~g}$ of coarsely ground pelleted samples (roller with a gap $0.203 \mathrm{~cm}$ ) and unprocessed samples were weighed into each numbered nylon bag with pore size of $40 \mu \mathrm{m}(\mathrm{Ni}-$ tex 03-41/31 monofilament open mash fabric, Screentec Corp., Mississauga, ON, Canada). The maximum nylon bags in each cow did not exceed 30, with the number of bags for longer incubation periods increased to ensure sufficient sample residual for chemical analysis. Ruminal incubation processes were carried out for 48, 24, $12,8,4,2$, and $0 \mathrm{~h}$ according to the gradual addition/ all-out schedule (Yu et al., 2000). At the end of incubation, incubated bags were taken out of the rumen, with all bags (incubated and $0 \mathrm{~h}$ bags) hand washed in cold water to rinse off ruminal contents. Washed bags were dried in a forced-air oven at $55^{\circ} \mathrm{C}$ for $48 \mathrm{~h}$, weighed, and dry residues in the bags were pooled according to the treatments, incubation time, and run. Pooled samples were then ground through a 1-mm screen using a Restch ZM 200 rotor mill (Rose Scientific Ltd., Edmonton, AB, Canada) for chemical analysis.

\section{Pelleting-Induced Changes in Rumen Degradation Kinetics}

To determine the degradation kinetics of DM, CP, and NDF, the first-order kinetics degradation model 
(Ørskov and McDonald, 1979) was used with an included lag time $\left(\mathbf{T}_{\mathbf{0}}, \mathrm{h}\right)$. The rumen undegradable fraction constant, degradation rate $\left(\mathbf{K}_{\mathbf{d}}, \% / \mathrm{h}\right)$ and $\mathrm{T}_{0}$, $\mathrm{h}$ were estimated from the in situ data using the nonlinear (PROC NLIN) procedure of SAS (version 9.3, SAS Institute Inc., Cary, NC) with iterative least-squares regression (Gauss-Newton method). The undegradable fraction $(\mathbf{U})$ of individual sample was computed from the nonlinear program.

The rumen degradable and rumen undegradable fractions of DM, CP, NDF, and $\mathrm{CHO}$ presented in percentage basis were computed using the mathematical equations of NRC (2001). The passage rate $\left(\mathbf{K}_{\mathrm{p}}\right)$ of $6 \% / \mathrm{h}$ (Tamminga et al., 1994) was used for the calculation of rumen degradable and rumen undegradable. The RUP content was determined according to the DVE/OEB system (RUP ${ }^{\text {DVE }}$; Tamminga et al., 1994) and the NRC dairy model (RUP $\left.{ }^{\text {NRC }} ; 2001\right)$. Detailed comparison of the concepts and formulas of NRC 2001 Model and DVE/OEB system for the prediction MP supply to dairy cow is reported earlier (Yu et al., 2003).

\section{Pelleting-Induced Changes In Hourly Effective Degradation Ratios and Potential N-to-Energy Synchronization}

The amount of nutrients degraded in each hour can be obtained by calculating the difference in cumulative hourly effective degradability (ED) between successive hours. Equations of Sinclair et al. (1993) were derived to calculate contents of hourly effectively degraded $\mathrm{N}$ and $\mathrm{OM}$ :

$$
\begin{gathered}
\text { Hourly ED }(\mathrm{g} / \mathrm{kg} \text { of } \mathrm{DM})= \\
\mathrm{S}+\left[\left(\mathrm{D} \times \mathrm{K}_{\mathrm{d}}\right) /\left(\mathrm{K}_{\mathrm{p}}+\mathrm{K}_{\mathrm{d}}\right)\right] \times\left[1-\mathrm{e}^{-\mathrm{t} \times\left(\mathrm{K}_{\mathrm{d}}+\mathrm{K}_{\mathrm{p}}\right)}\right] .
\end{gathered}
$$

where $\mathrm{t}$ is incubation time (h). Hourly ED ratio of $\mathrm{N}$ to $\mathrm{OM}$ and hourly ED ratio of $\mathrm{N}$ to $\mathrm{CHO}$ were calculated using following equations (Nuez-Ortín and Yu, 2010):

$$
\begin{gathered}
\text { Hourly ED ratio N/OM }=\left(\mathrm{HEDN}_{\mathrm{t}}-\mathrm{HEDN}_{\mathrm{t}-1}\right) / \\
\left(\mathrm{HEDOM}_{\mathrm{t}}-\mathrm{HEDOM}_{\mathrm{t}-1}\right) ; \\
\text { Hourly ED ratio N/CHO } \\
\times\left(\mathrm{HEDN}_{\mathrm{t}}-1,000\right. \\
+\left(\mathrm{HEDN}_{\mathrm{t}-1}\right) /\left[\left(\mathrm{HEDNDF}_{\mathrm{t}}-\mathrm{HEDNDF}_{\mathrm{t}-1}\right)\right. \\
\left.\left.+\mathrm{HEDNFC}_{\mathrm{t}-1}\right)\right] .
\end{gathered}
$$

where $\mathrm{N} / \mathrm{OM}_{\mathrm{t}}$ is the ratio of $\mathrm{N}$ to $\mathrm{OM}$ ( $\mathrm{g}$ of $\mathrm{N} / \mathrm{kg}$ of $\mathrm{OM}) ; \mathrm{N} / \mathrm{CHO}_{\mathrm{t}}$ is the ratio of $\mathrm{CHO}$ at time $\mathrm{t}(\mathrm{g} \mathrm{N} / \mathrm{kg}$ of CHO); HEDN $, H_{t}, \mathrm{HEOM}_{t}, \mathrm{HEDCHO}_{\mathrm{t}}, \mathrm{HEDNDF}_{\mathrm{t}}$, and $\mathrm{HEDNFC}_{\mathrm{t}}$ are the hourly effective degradabilities of $\mathrm{N}$,
$\mathrm{OM}, \mathrm{CHO}, \mathrm{NDF}$, and $\mathrm{NFC}$ at time $\mathrm{t}(\mathrm{g} / \mathrm{kg}$ of $\mathrm{DM})$, respectively; $\mathrm{HEDN}_{\mathrm{t}-1}, \mathrm{HEDOM}_{\mathrm{t}-1}, \mathrm{HEDNDF}_{\mathrm{t}-1}$, and $\mathrm{HEDNFC}_{\mathrm{t}-1}$ are the hourly effective degradabilities of $\mathrm{N}, \mathrm{OM}, \mathrm{NDF}$, and NFC at time of $1 \mathrm{~h}$ before $\mathrm{t}(\mathrm{g} / \mathrm{kg}$ of $\mathrm{DM})$, respectively.

\section{Pelleting-Induced Changes In Intestinal Digestibility of Nutrients}

The intestinal digestibility of RUP (dRUP) was estimated according to the 3 -step in vitro procedure of Calsamiglia and Stern (1995). The detailed information regarding the rumen incubation period and quantity of residues used for the dRUP analysis is reported earlier (Khan et al., 2015). The total-tract digestion of CHO, NDF, and DM were also estimated according to literature (Nuez-Ortín and Yu, 2010). For total-tract digestion of NDF, it was assumed that the NDF that was not degraded in the rumen after the longest incubation $(48 \mathrm{~h})$ could not be digested in the small intestine (Yang et al., 2013).

\section{Chemical Analysis}

For chemical analysis, all samples were ground through a 1-mm screen using a Restch ZM 200 rotor mill (Rose Scientific Ltd.). Dry matter (method 930.15), ash (942.05), ether extract (EE; method 954.02), and CP (method 984.13) were analyzed according to the official methods of AOAC (2005). The content of NDF was determined with the filter bag technique (Ankom Technology Corp., Fairport, NY) according to the methods of Van Soest et al. (1991). Sodium sulfite and heat stable amylase were used during neutral detergent extraction to remove the residual $\mathrm{N}$ and starch.

The methods in Licitra et al. (1996) were applied to analyze acid detergent insoluble crude protein (ADICP) and neutral detergent insoluble crude protein (NDICP). The samples were incubated with bicarbonate-phosphate buffer then filtered through the \#54 Whatman filter papers to determine the content of total soluble crude protein (SP; Licitra et al., 1996). For determination of NPN, tungstic acid was used to precipitate the true protein fraction, and then the difference between total $\mathrm{CP}$ and precipitated $\mathrm{CP}$ was considered as NPN. Total CHO was calculated as 100 $-(\% \mathrm{EE}+\% \mathrm{CP}+\%$ ash $)$, and NFC was calculated as $\mathrm{NFC}=100-(\% \mathrm{CP}+(\% \mathrm{NDF}-\% \mathrm{NDIP})+\%$ fat + \%ash) according to NRC (2001).

\section{Statistical Analysis}

These series of experiments were designed using the randomized complete block design (RCBD) with a $3 \times$ 
2 factorial treatment arrangement. Statistical analyses were performed through MIXED procedure of SAS 9.3 (SAS Institute Inc., Cary, NC).

For the analyses of the in situ degradation kinetics, intestinal digestibility (in vitro) of rumen undegraded nutrients, degradability ratios of $\mathrm{N} / \mathrm{CHO}$ and $\mathrm{N} / \mathrm{OM}$, and for hourly effective degradability ratios, the following model was used:

$$
Y_{i j l r}=\mu+\alpha_{i}+\beta_{j}+\gamma_{k}+\eta_{l}+e_{i j l r}
$$

where $Y_{i j l r}$ was an observation of the dependent variable $i j l r ; \mu$ was the population mean for variable; $\alpha_{i}$ was the effect of conditioning temperature; $\beta_{j}$ was the effect of conditioning time; $\gamma_{k}$ was the interaction of conditioning time and temperature $\left(\gamma_{k}=\alpha_{i} \times \beta_{j}\right) ; \eta_{l}$ was the effect of batch as a random effect; $e_{i j l r}$ was random errors associated with observation ijlr. The normality tests were performed using UNIVARIATE procedure of SAS with NORMAL and PLOT options.

Contrast statement was performed to detect the difference between the unprocessed mash and pellets. Also, orthogonal polynomial contrasts (linear and quadratic) of conditioning temperature $\left(70,80\right.$, and $\left.90^{\circ} \mathrm{C}\right)$ were performed if conditioning temperature was significant in overall $F$-test. The significance level was declared at $P<0.05$ and trends at $P<0.10$.

\section{RESULTS AND DISCUSSION}

\section{Pelleting-Induced Changes in In Situ Degradation Kinetics of Canola Meal}

In Situ DM Degradation Kinetics. The interaction effect of conditioning time and temperature on DM degradation parameter, namely, S, D, and U fractions, $\mathrm{K}_{\mathrm{d}}$, and effective degradability of DM (EDDM), was not significant (Table 1). Moreover, all the DM degradation parameters and EDDM of the pellets were not different from the raw mash meal. Conditioning time did not alter the EDDM. However, pellets conditioned for $75 \mathrm{~s}$ had higher $(P=0.04 ; 69.1$ vs. $67.3 \% \mathrm{DM})$ D-fraction of DM than those conditioned for $50 \mathrm{~s}$, indicating that D-fraction of DM was increased by increasing conditioning time. The pellets conditioned at $80^{\circ} \mathrm{C}$ tended to have higher $(P=0.07)$ EDDM compared with the pellets conditioned at $70^{\circ} \mathrm{C}$ and $90^{\circ} \mathrm{C}$. The Dfraction decreased when the pellets were conditioned at $80^{\circ} \mathrm{C}$, and the S-fraction only increased numerically; therefore, the higher EDDM of pellets conditioned at $80^{\circ} \mathrm{C}$ is mainly caused by the higher $(P=0.06) \mathrm{K}_{\mathrm{d}}(11.2$ vs. 9.5 and $9.2 \% / \mathrm{h}$ ) of D-fraction. No study in literature was found that has evaluated the effect of similar conditioning temperature and time during pelleting of canola meal that could be used to compare with the findings of this study. In contrast to the current study, McKinnon et al. (1995) observed that dry heating/ toasting of canola at 125 and $145^{\circ} \mathrm{C}$ for 10 to $30 \mathrm{~min}$ decreased EDDM. Discrepancy between the 2 studies may be due to the differences in processing methods (pelleting vs. dry roasting), temperatures $\left(70-90^{\circ} \mathrm{C}\right.$ vs. $\left.125-145^{\circ} \mathrm{C}\right)$, and processing time $(50-75$ s vs. $10-30$ $\min )$.

Detailed observation of the data revealed that the higher DM degradability of the pellets conditioned at $80^{\circ} \mathrm{C}$ was mainly related to the higher $\mathrm{K}_{\mathrm{d}}$ of $\mathrm{CP}$ and higher S-fraction of NDF (Tables 2 and 3). Heat processing alters EDDM of protein feeds by altering the protein molecular structures, such as the uncoiling of pleated structures or denaturation of the whole protein molecules. These heat-induced structural changes expose the intact AA, and subsequently results in the development of cross-linkages among peptides/AA, and between AA and carbohydrates (Yan et al., 2014). Both temperature and duration of heating play a key role in the level of denaturation and development of cross linkages, and hence the protection of feed against rumen degradation (Khan et al., 2015). Extensive research has shown that only extensive cross linkages between protein and carbohydrates that stabilize their internal molecular structures can reduce feed solubility and ruminal degradability. Whereas under-heating of protein feeds can actually increase their degradability by exposing new sites for microbial and enzymatic attack (Camire et al., 1990; Voragen et al., 1995; Abdollahi et al., 2013). Goelema et al. (1999) and Abdollahi et al. (2013) reported that a partial denaturation of protein during pellet processing increases protein degradability (Goelema et al., 1999; Abdollahi et al., 2013). The later could, in part, explain the results of the current study.

In Situ CP Degradation Kinetics. The interaction effect of conditioning temperature and time on all measured in situ CP degradation parameters was not significant (Table 2). The pellets had a higher $(P<$ $0.01) \mathrm{K}_{\mathrm{d}}$ of D-fraction and higher $(P<0.01) \mathrm{RDP}$ fraction as compared with raw meals, indicating that pelleting shifted CP digestion to the rumen rather than to the small intestine. Conditioning temperature affected $(P=0.01)$ the RDP content of canola meal pellets in a quadratic fashion, with samples conditioned at $80^{\circ} \mathrm{C}$ having higher RDP content (62.4 vs. 60.9 and $58.6 \%$ $\mathrm{CP})$ compared with pellets conditioned at $70^{\circ} \mathrm{C}$ and $90^{\circ} \mathrm{C}$. The S-fraction of $\mathrm{CP}$ decreased consistently $(P<$ 0.01 ) with increasing conditioning temperature, and the D-fraction increased consistently $(P=0.02)$, with the highest D-fraction being recorded for pellet condition at $90^{\circ} \mathrm{C}$ (Table 2). These results show that the higher $\mathrm{RDP}$ in pellets conditioned at $80^{\circ} \mathrm{C}$ was mainly caused 
Table 1. Effects of conditioning temperature and time during the pelleting process on processing-induced changes in in situ rumen degradation characteristics of DM of canola meal

of $\mathrm{DMI}^{1}$

$\mathrm{K}(\% / \mathrm{h}$

$\mathrm{K}_{\mathrm{d}}(\% / \mathrm{h})$

$\mathrm{S}(\% \mathrm{DM})$

$\mathrm{D}(\% \mathrm{DM})$

$\mathrm{U}(\%$ DM)

RUDM (g/kg, DM)

$\operatorname{EDDM}(\mathrm{g} / \mathrm{kg}, \mathrm{DM})$

Conditioning

temperature (Temp)

fraction; $\mathrm{T}$

$\mathrm{RUDM}=$ rumen undegraded DM; EDDM = effectively degraded DM; $\mathrm{L}=$ linear; $\mathrm{Q}=$ quadratic.

\begin{tabular}{rrlllllllllllr}
9.5 & 11.2 & 9.2 & 0.59 & 10.0 & 9.9 & 0.48 & 0.06 & 0.80 & 0.77 & 0.73 & 0.02 & 10.4 & 0.67 \\
0.1 & 0.3 & 0.1 & 0.16 & 0.2 & 0.1 & 0.14 & 0.31 & 0.89 & 0.71 & 0.94 & 0.13 & 0.0 & 0.43 \\
14.1 & 14.7 & 15.1 & 0.61 & 15.1 & 14.2 & 0.54 & 0.40 & 0.13 & 0.59 & 0.19 & 0.87 & 14.4 & 0.71 \\
68.7 & 67.5 & 68.4 & 1.85 & 67.3 & 69.1 & 1.81 & 0.44 & 0.04 & 0.89 & 0.81 & 0.22 & 67.9 & 0.86 \\
17.2 & 17.8 & 16.5 & 1.38 & 17.6 & 16.8 & 1.35 & 0.16 & 0.16 & 0.88 & 0.26 & 0.12 & 17.8 & 0.65 \\
440 & 418 & 436 & 10.3 & 432 & 430 & 9.65 & 0.07 & 0.77 & 0.99 & 0.65 & 0.02 & 444 & 0.23 \\
560 & 582 & 564 & 10.3 & 568 & 570 & 9.7 & 0.06 & 0.77 & 0.99 & 0.65 & 0.02 & 556 & 0.23 \\
\hline
\end{tabular}



compared with the pellets conditioned at 70 and $90^{\circ} \mathrm{C}$.

In agreement with our finding the S-fraction of $\mathrm{CP}$ decreased $(P<0.05)$ after autoclaving of flaxseed at $120^{\circ} \mathrm{C}$ for 10 to $30 \mathrm{~min}$ (Doiron et al., 2009), roasting of canola meal at $150^{\circ} \mathrm{C}$ for 105 min (Plaisance et al., 1997), and autoclaving of sunflower seed at $127^{\circ} \mathrm{C}$ for 10 to 30 min (Mustafa et al., 2003). As discussed earlier, heat-processing decreases $\mathrm{CP}$ solubility by altering protein molecular structures. However, research has demonstrated that the RDP fraction of $\mathrm{CP}$ is reduced only when the protein feeds are heated at a higher temperature and for a longer duration. The later results in the development of complex cross linkages and advanced Maillard products that protect $\mathrm{CP}$ against rumen degradation. In the present study, pellet conditioning reduced the S-fraction of $\mathrm{CP}$ but did not reduce the RDP content, which shows that heating temperature and duration was not optimal to protect $\mathrm{CP}$ against rumen degradation. The first part of this study has reported that conditioning during the pellet processing altered the primary structures of protein molecules (Huang et al., 2015). It can be envisaged that due to sub-optimal (lower temperature, short duration, or both) heating during pellet processing, the complex cross-linkages among the free peptides/AA and sugars were not established. As a consequence, the structural alterations in protein molecules increased the availability of new sites for microbial and enzymatic attack, causing higher degradation of $\mathrm{CP}$ in pelleted meals (Camire et al., 1990; Voragen et al., 1995; Abdollahi et al., 2013). In agreements with our findings, conditioning at $80^{\circ} \mathrm{C}$ for $10 \mathrm{~s}$ during pellet processes increased the RDP content of a mixture of broken peas, lupins, and fava beans (Goelema et al., 1999) and 2 compound feeds/concentrates (Goelema et al., 1996). Moreover, from literature review Abdollahi et al. (2013) concluded that the partial denaturation of protein during pellet processing improves CP degradability by exposing new sites for enzymatic attack.

In contrast to our findings, moist heating at $127^{\circ} \mathrm{C}$ for 15 to $90 \mathrm{~min}$ (Nia and Ingalls, 1992), dry heating at 125 and $145^{\circ} \mathrm{C}$ for 10 to $30 \mathrm{~min}$ (McKinnon et al., 1995), roasting at $150^{\circ} \mathrm{C}$ for $105 \mathrm{~min}$ (Plaisance et al., 1997), and microwave irradiation for 2 to 6 min (Sadeghi and Shawrang, 2006) significantly reduced the RDP content of canola meal and increased the supply of RUP to the postruminal tract. As discussed earlier, the discrepancy among the studies is mainly related to the method, temperature, and duration of heating that all affects the inherent changes in protein molecular structures and its resistance against ruminal degradation and intestinal digestion. This discussion provides the impetus to study the effect of higher conditioning temperature 
and time on $\mathrm{CP}$ degradation characteristics of pellets produced from protein ingredients.

In Situ NDF Degradation Kinetics. The interaction of effect of conditioning temperature and time on all measured in situ NDF degradation parameters and effective degradability of NDF (RDF) was not significant $(P>0.10$; Table 3$)$. Pelleted meals were higher $(P$ $=0.02)$ in $\mathrm{RDF}(\mathrm{g} / \mathrm{kg}$ of DM) than the raw mash meal, suggesting that more NDF was degraded in the rumen and that RUF was reduced after pelleting. Conditioning temperature had a quadratic effect $(P<0.01)$ on the content of RDF, and pellets conditioned at $80^{\circ} \mathrm{C}$ had the highest content of RDF (35.5\% NDF). The $\mathrm{K}_{\mathrm{d}}$ of NDF was not affected by conditioning temperature. Samples conditioned at $80^{\circ} \mathrm{C}$ tended $(P=0.06)$ to have the lowest D-fraction of NDF $(49.3 \% \mathrm{NDF})$ compared with those conditioned at $70^{\circ} \mathrm{C}$ and $90^{\circ} \mathrm{C}$. The higher $\mathrm{RDF}$ content of the samples conditioned at $80^{\circ} \mathrm{C}$ was mainly caused by the higher S-fraction (5.9 vs. 1.7 and $1.9 \% \mathrm{NDF}$ ) compared with the samples conditioned at $70^{\circ} \mathrm{C}$ and $90^{\circ} \mathrm{C}$. Moreover, the S-fraction increased $(P$ $=0.03 ; 1.5$ to $4.8 \% \mathrm{NDF}$ ) when the conditioning time increased from 50 to $75 \mathrm{~s}$. In situ rumen degradability of NDF is affected by physico-chemical changes such as by development of cross linkages between protein and carbohydrates, as well as by the physical characteristics such as particle size. Goelema et al. (1999) argued that the reduction in particles size due to fine grinding before pellet processing (Abdollahi et al., 2013), and during the pellet process such as due to pressure and shear, is the main cause of increased S-fraction, $\mathrm{K}_{\mathrm{d}}$, and effective degradability of pelleted feeds compared with raw feeds. The smaller particles escape quickly from the nylon bags that are reflected in the higher S-fraction, $\mathrm{K}_{\mathrm{d}}$, and effective degradability. It may be noted that the increase in fiber degradability in the pelleted meal, due to the escape of smaller particles from the nylon bags, does not mean an increase in fiber fermentation in the rumen. The smaller feed particles have high passage rate and as such may pass from the rumen undegraded.

\section{Pelleting-Induced Changes in Hourly Effectively Rumen Degradation Ratios and Potential N to Energy Synchronization}

For dairy cattle, the optimal ratio between effective degradability of $\mathrm{N}$ and energy to achieve maximum microbial synthesis and minimum $\mathrm{N}$ loss is $32 \mathrm{~g}$ of $\mathrm{N} /$ $\mathrm{kg}$ of $\mathrm{CHO}$ or $25 \mathrm{~g}$ of $\mathrm{N} / \mathrm{kg}$ of $\mathrm{OM}$ (Sinclair et al., 1993; Tamminga et al., 2007). Moreover, a higher ratio than the optimal indicates a potential loss of $\mathrm{N}$ from the rumen or deficiency of energy supply to the rumen microbes, and a lower ratio than the optimal indicate a shortage of $\mathrm{N}$ for microbial growth (Nuez-Ortín and
$\mathrm{Yu}, 2010)$. Feed processing is often used to synchronize the ratio of rumen degraded $\mathrm{N}$ and energy. In the current study, the ratios of effectively degraded $\mathrm{N}$ to effectively degraded CHO (ED-N/ED-CHO) and the ratio of effectively degraded $\mathrm{N}$ to effectively degraded OM (ED-N/ED-OM) of raw and pelleted canola meal were higher than the optimal, when evaluated as a single ingredient. Revealing that with the feeding of canola meal extra $\mathrm{N}$ is produced in rumen that is not captured for microbial protein synthesis. The extra $\mathrm{N}$ will increase $\mathrm{NH}_{3}$ concentration in the rumen, which is absorbed into the bloodstream, converted to urea in the liver, and excreted in urine. This implies that elevated level of canola meal in dairy ration will have repercussions both on animal performance in terms of extra metabolic cost associated with excreting $\mathrm{N}$, and on environment, because they lead to soil $\mathrm{N}$ accumulation. Alternatively, supplementation of ME-rich feeds will be required to correct the $\mathrm{N}$ excess and optimize microbial CP synthesis.

The ratios of ED-N/ED-CHO $(P=0.06)$ and the ratio ED-N/ED-OM $(P=0.08)$ of canola meal pellets decreased with increasing conditioning temperature, indicating that the increase in heating temperature from 70 to $90^{\circ} \mathrm{C}$ improved $\mathrm{N}$ and energy synchronization in canola meal (Table 4). However, pellets had higher average values of the ED-N/ED-CHO $(P<$ $0.01)$ and ED-N/ED-OM $(P=0.03)$ ratios than unprocessed mash. This means the pellet processing of canola meal under the condition of the present study leads to higher $\mathrm{N}$ losses than the raw meal. The hourly ED-N/ $\mathrm{ED}-\mathrm{CHO}$ ratio increased rapidly from 0 to $2 \mathrm{~h}$ for all treatments, demonstrating a rapid increase in $\mathrm{N}$ concentration in the rumen during the first $2 \mathrm{~h}$ of canola feeding. Yu et al. (2009) and Nuez-Ortín and Yu (2010) indicated that the difference in hourly degradation of $\mathrm{N}$ was a main reason to change the hourly ED-N/ED$\mathrm{CHO}$ ratio. Thus, the difference between unprocessed mash and pelleted samples in hourly ED-N/ED-CHO was likely due to the increased CP degradation caused by pelleting.

\section{Pelleting-Induced Changes in Intestinal Digestive Characteristics of Nutrients of Canola Meal}

Previous studies show that it is important to evaluate the intentional digestibility of RUP after heat-related processing of protein feeds, because overheating can overprotect CP from intestinal digestion (Khan et al., 2015). Data in Table 5 show that conditioning temperature $(P=0.55)$ and time $(P=0.44)$ used in the current study did not alter the intestinal digestibility of RUP in the pellets. Conditioning temperature tended $(P=0.09)$ to have a significant effect on the quantity 
Table 4. Effects of conditioning temperature and time during the pelleting process on processing-induced changes in degradability ratios between $\mathrm{N}$ and carbohydrates (CHO), N, and $\mathrm{OM}$, and hourly effective degradability ratios in canola meal

\begin{tabular}{|c|c|c|c|c|c|c|c|c|c|c|c|c|c|c|}
\hline \multirow[b]{2}{*}{ Item $^{1}$} & \multicolumn{3}{|c|}{$\begin{array}{c}\text { Conditioning } \\
\text { temperature (Temp) }\end{array}$} & \multirow[b]{2}{*}{ SEM } & \multicolumn{2}{|c|}{$\begin{array}{l}\text { Conditioning } \\
\text { time (Time) }\end{array}$} & \multirow[b]{2}{*}{ SEM } & \multicolumn{3}{|c|}{$P$-value } & \multicolumn{2}{|c|}{$\begin{array}{l}\text { Polynomial contrast } \\
\text { for Temp ( } P \text {-value })\end{array}$} & \multirow[b]{2}{*}{$\begin{array}{c}\text { Control } \\
\text { (raw) }\end{array}$} & \multirow{2}{*}{$\begin{array}{c}\begin{array}{c}\text { Contrast } \\
P \text {-value }\end{array} \\
\begin{array}{c}\text { Control vs } \\
\text { processed }\end{array}\end{array}$} \\
\hline & $70^{\circ} \mathrm{C}$ & $80^{\circ} \mathrm{C}$ & $90^{\circ} \mathrm{C}$ & & $50 \mathrm{~s}$ & $75 \mathrm{~s}$ & & Temp & Time & $\begin{array}{l}\text { Temp } \\
\times \text { Time }\end{array}$ & $\mathrm{L}$ & Q & & \\
\hline \multicolumn{15}{|c|}{$\mathrm{N}$-to-OM and $\mathrm{N}$-to-CHO ratios } \\
\hline $\mathrm{N} / \mathrm{OM}$ & 69.1 & 69.0 & 68.7 & 1.97 & 68.7 & 69.2 & 1.97 & 0.63 & 0.10 & 0.93 & 0.36 & 0.82 & 68.8 & 0.82 \\
\hline $\mathrm{N} / \mathrm{CHO}$ & 126 & 124 & 124 & 6.26 & 124 & 126 & 6.23 & 0.73 & 0.11 & 0.81 & 0.47 & 0.76 & 124 & 0.72 \\
\hline ED-N/ED-OM & 76.5 & 74.9 & 72.8 & 1.20 & 73.7 & 75.7 & 1.05 & 0.06 & 0.10 & 0.84 & 0.02 & 0.83 & 71.3 & 0.03 \\
\hline ED-N/ED-CHO & 147 & 144 & 136 & 3.61 & 139 & 147 & 3.02 & 0.08 & 0.07 & 0.64 & 0.03 & 0.62 & 126 & $<0.01$ \\
\hline \multicolumn{15}{|c|}{ Hourly effective degradability ratios of $\mathrm{N} / \mathrm{CHO}$ at individual time } \\
\hline $0 \mathrm{~h}$ & 96.1 & 68.8 & 48.7 & 15.8 & 54 & 88.0 & 14.2 & 0.04 & 0.03 & 0.49 & 0.01 & 0.81 & 30.5 & 0.03 \\
\hline $2 \mathrm{~h}$ & 170 & 176 & 179 & 9.82 & 184 & 166 & 8.78 & 0.72 & 0.05 & 0.09 & 0.43 & 0.89 & 162 & 0.25 \\
\hline $4 \mathrm{~h}$ & 178 & 184 & 189 & 9.29 & 192 & 177 & 8.64 & 0.41 & 0.04 & 0.09 & 0.19 & 0.93 & 177 & 0.49 \\
\hline $8 \mathrm{~h}$ & 192 & 120 & 208 & 13.4 & 205 & 196 & 13.2 & 0.02 & 0.02 & 0.26 & $<0.01$ & 0.95 & 204 & 0.50 \\
\hline $12 \mathrm{~h}$ & 204 & 213 & 222 & 18.1 & 217 & 209 & 17.9 & 0.04 & 0.19 & 0.58 & 0.01 & 0.97 & 227 & 0.10 \\
\hline $24 \mathrm{~h}$ & 215 & 230 & 232 & 21.9 & 233 & 219 & 20.4 & 0.64 & 0.39 & 0.29 & 0.39 & 0.71 & 261 & 0.13 \\
\hline
\end{tabular}

${ }^{1} \mathrm{ED}=$ effective degradability; $\mathrm{L}=$ linear; $\mathrm{Q}=$ quadratic; ratio unit for N/OM and ED-N/ED-OM: g of N/kg of OM; ratio unit for N/CHO and ED-N/ED-CHO: g of N/kg of CHO.

Table 5. Effects of conditioning temperature and time during the pelleting process on processing-induced changes in digestion and availability of $\mathrm{CP}$, carbohydrates (CHO), and NDF in canola meal

\begin{tabular}{|c|c|c|c|c|c|c|c|c|c|c|c|c|c|c|}
\hline \multirow[b]{2}{*}{ Item $^{1}$} & \multicolumn{3}{|c|}{$\begin{array}{c}\text { Conditioning } \\
\text { temperature (Temp) }\end{array}$} & \multirow[b]{2}{*}{ SEM } & \multicolumn{2}{|c|}{$\begin{array}{l}\text { Conditioning } \\
\text { time (Time) }\end{array}$} & \multirow[b]{2}{*}{ SEM } & \multicolumn{3}{|c|}{$P$-value } & \multicolumn{2}{|c|}{$\begin{array}{l}\text { Polynomial contrast } \\
\text { for Temp ( } P \text {-value) }\end{array}$} & \multirow{2}{*}{$\begin{array}{l}\text { Control } \\
\text { (raw) }\end{array}$} & \multirow{2}{*}{$\begin{array}{c}\begin{array}{c}\text { Contrast } \\
P \text {-value }\end{array} \\
\begin{array}{c}\text { Control vs } \\
\text { processed }\end{array}\end{array}$} \\
\hline & $70^{\circ} \mathrm{C}$ & $80^{\circ} \mathrm{C}$ & $90^{\circ} \mathrm{C}$ & & $50 \mathrm{~s}$ & $75 \mathrm{~s}$ & & Temp & Time & $\times$ Time & $\mathrm{L}$ & $\mathrm{Q}$ & & \\
\hline $\begin{array}{l}\text { CP intestinal digestion } \\
\text { dRUP }(\%)\end{array}$ & 61.3 & 59.2 & 60.5 & 1.33 & 60.9 & 59.7 & 1.09 & 0.55 & 0.44 & 0.60 & 0.70 & 0.32 & 64.2 & 0.06 \\
\hline IDP ( $\%$ of CP) & 24.0 & 22.3 & 25.0 & 0.83 & 24.5 & 23.1 & 0.68 & 0.09 & 0.16 & 0.66 & 0.41 & 0.04 & 28.4 & $<0.01$ \\
\hline IDP $(\mathrm{g} / \mathrm{kg}, \mathrm{DM})$ & 96.1 & 89.0 & 100 & 4.52 & 97.1 & 92.2 & 4.12 & $<0.10$ & 0.20 & 0.69 & 0.49 & 0.04 & 113 & $<0.01$ \\
\hline TDP $(\% \mathrm{CP})$ & 84.9 & 84.7 & 83.7 & 0.49 & 84.4 & 84.5 & 0.40 & 0.21 & 0.84 & 0.67 & 0.10 & 0.56 & 84.2 & 0.73 \\
\hline TDP (g/kg, DM) & 340 & 338 & 334 & 10.7 & 336 & 339 & 10.5 & 0.29 & 0.44 & 0.86 & 0.12 & 0.85 & 336 & 0.79 \\
\hline NDF total digestion & & & & & & & & & & & & & & \\
\hline TDNDF ( $\%$ of NDF) & 51.3 & 53.8 & 52.1 & 2.60 & 50.6 & 54.2 & 2.56 & 0.13 & $<0.01$ & 0.41 & 0.48 & 0.06 & 50.6 & 0.19 \\
\hline TDNDF (g/kg, DM) & 156 & 169 & 156 & 4.21 & 150 & 170 & 3.53 & 0.05 & $<0.01$ & 0.09 & 0.90 & 0.02 & 143 & 0.01 \\
\hline
\end{tabular}


of total intestinal digestible protein (IDP), and pellets conditioned at $90^{\circ} \mathrm{C}$ had the higher IDP content than those conditioned at 70 or $80^{\circ} \mathrm{C}$. This is consistent with the in situ results, which showed a higher $(P=0.01)$ content of RUP in canola meal pellets conditioned at $90^{\circ} \mathrm{C}$. Moreover, extensive research shows that increasing heating temperature or duration often reduces $\mathrm{CP}$ degradability in the rumen and increases the supply of RUP to the small intestine (Petit et al., 2002; Doiron et al., 2009). The unprocessed meal tended to have higher $(P=0.06)$ intestinal digestibility of RUP and higher $(P<0.01)$ IDP than the pellets. This was likely due to the decrease in RUP supply to the small intestine after pelleting in this study. However, the total digestible protein content did not differ due to pellet processing, indicating that pelleting under different conditioning temperatures and time evaluated in this study did not change total digestible protein of canola meal.

Altering conditioning temperature and time did not alter intestinal digestion of NDF (Table 5). However, total digestible NDF content altered $(P<0.01)$ with conditioning time. The samples conditioned for $75 \mathrm{~s}$ were higher in total digestible NDF than those conditioned for $50 \mathrm{~s}$. The total digestible NDF content $(\mathrm{g} /$ $\mathrm{kg}, \mathrm{DM})$ of the pellets was higher $(P=0.01)$ than that of the unprocessed mash meal.

\section{ACKNOWLEDGMENTS}

The authors thank Zhiyuan Niu (Department of Animal and Poultry Science, University of Saskatchewan) and Louis L. Roth (Department of Chemical and Biological Engineering, College of Engineering, University of Saskatchewan) for their help in laboratory analysis, pelleting, and animal study; Lee-Anne Walter for kind help in editing this manuscript; F. Buchanan, C. Christensen, and T. Scott (University of Saskatchewan, Saskatoon, Canada) for sitting on the graduate student (Xuewei Huang) advisory committee to provide valuable discussion and suggestions. Financial support for Feed Research Chair (Peiqiang Yu) Programs was provided by the Ministry of Agriculture Strategic Research Chair Program, SaskCanola (Saskatoon, Canada), Natural Sciences and Engineering Research Council of Canada (NSERC-Individual discovery grant and Collaborative Research and Development Grants), Thousand-Talent People Research Program (Tianjin, China) and University Innovation Team "Veterinary Biotechnology" (TD12-5019, Tianjin), the Saskatchewan Agriculture Development Fund (ADF, Regina, Canada), SaskMilk (Regina, Canada), Saskatchewan Forage Network (SNK, Saskatchewan, Canada), Saskatchewan Pulse Producers, and Western Grain Research Foundation (WGRF, Saskatoon, Canada).

\section{REFERENCES}

Abdollahi, M. R., V. Ravindran, and B. Svihus. 2013. Pelleting of broiler diets: An overview with emphasis on pellet quality and nutritional value. Anim. Feed Sci. Technol. 179:1-23.

AOAC International. 2005. Official Methods of Analysis, 18th ed. AOAC Int., Arlington, VA.

Calsamiglia, S., and M. D. Stern. 1995. A three-step in vitro procedure for estimating intestinal digestion of protein in ruminants. J. Anim. Sci. 73:1459-1465.

Camire, M. E., A. Camire, and K. Krumhar. 1990. Chemical and nutritional changes in food during extrusion. Crit. Rev. Food Sci. Nutr. 29:35-57.

Canola Council of Canada. 2013. The Economic Impact of Canola on the Canadian Economy. Accessed May 2014. http://www. canolacouncil.org/media/545722/lmc_economic_impact_of_ canola_on_the_canadian_economy_october_2013.pdf.

CCAC. 1993, Guide to the Care and Use of Experimental Animals, 2nd ed. Canadian Council of Animal Care, Ottawa, Canada.

Doiron, K., P. Yu, J. J. McKinnon, and D. A. Christensen. 2009. Heat-induced protein structures and protein subfractions in relation to protein degradation kinetics and intestinal availability in dairy cattle. J. Dairy Sci. 92:3319-3330.

Goelema, J. O., G. Hof, A. F. B. Van der Poel, and S. Tamminga. 1996. Effect of particle size, cold pelleting, steam pelleting and expander treatment on the rumen degradability of a compound feed for ruminants. J. Dairy Sci. 79(Suppl. 1):142.

Goelema, J. O., A. Smits, L. M. Vaessen, and A. Wemmers. 1999. Effects of pressure toasting, expander treatment and pelleting on in vitro and in situ parameters of protein and starch in a mixture of broken peas, lupins and faba beans. Anim. Feed Sci. Technol. 78:109-126.

Heendeniya, R. G., D. A. Christensen, D. D. Maenz, J. J. McKinnon, and P. Yu. 2012. Protein fractionation byproduct from canola meal for dairy cattle. J. Dairy Sci. 95:4488-4500.

Huang, X., C. Christensen, and P. Yu. 2015. Effects of conditioning temperature and time during the pelleting process on feed molecular structure, pellet durability index, and metabolic features of co-products from bio-oil processing in dairy cows. J. Dairy Sci. 98: 4869-4881.

Khan, N. A., H. Booker, and P. Yu. 2015. Effect of heating method on alteration of protein molecular structure in flaxseed: Relationship with changes in protein subfraction profile and digestion in dairy cows. J. Agric. Food Chem. 63:1057-1066.

Licitra, G., T. M. Hernandez, and P. J. van Soest. 1996. Standardization of procedures for nitrogen fractionation of ruminant feeds. Anim. Sci. Feed. Technol. 57:347-358.

McKinnon, J. J., J. A. Olubobokun, A. Mustafa, R. D. H. Cohen, and D. A. Christensen. 1995. Influence of dry heat treatment of canola meal on site and extent of nutrient disappearance in ruminants. J. Anim. Feed Sci. Technol. 56:243-252.

Mustafa, A. F., Y. P. Chouinard, D. R. Ouellet, and H. Soita. 2003. Effects of moist heat treatment on ruminal nutrient degradability of sunflower seed. J. Sci. Food Agric. 83:1059-1064.

Newkirk, R. 2009a. Canola Meal Feed IndustryGuide. 4th ed. Accessed May 2014. http://www.canolacouncil.org/media/516716/ canola_meal_feed_guide_english.pdf.

Newkirk, R. 2009b. Meal nutrient composition. J. K. Daun, N. A. M. Eskin, and D. Hickling, ed. Pages 229-242 in Canola Chemistry, Production, Processing, and Utilization. AOCS Press, Urbana, IL.

Nia, S. M., and J. R. Ingalls. 1992. Effect of heating on canola meal protein degradation in the rumen and digestion in the lower gastrointestinal tract of steers. Can. J. Anim. Sci. 72:83-88.

NRC. 2001. Nutrient Requirement of Dairy Cattle. 7th ed. National Academies of Science, Washington, DC.

Nuez-Ortín, W. G., and P. Yu. 2010. Estimation of ruminal and intestinal digestion profiles, hourly effective degradation ratio and potential $\mathrm{N}$ to energy synchronization of co-products from bioethanol processing. J. Sci. Food Agric. 90:2058-2067.

Ørskov, E. R., and I. McDonald. 1979. The estimation of protein degradability in the rumen from incubation measurements weighted according to rate of passage. J. Agric. Sci. 92:499-503. 
Petit, H. V., G. F. Tremblay, E. Tremblay, and P. Nadeau. 2002. Ruminal biohydrogenation of fatty acids, protein degradability and dry matter digestibility of flaxseed treated with different sugar and heat combinations. Can. J. Anim. Sci. 82:241-250.

Plaisance, R., H. V. Petit, J. R. Seoane, and R. Rioux. 1997. The nutritive value of canola, heat-treated canola and fish meals as protein supplements for lambs fed grass silage. J. Anim. Feed Sci. Technol. 68:139-152.

Sadeghi, A. A., and P. Shawrang. 2006. Effects of microwave irradiation on ruminal degradability and in vitro digestibility of canola meal. Anim. Feed Sci. Technol. 127:45-54.

Sinclair, L. A., P. C. Garnsworthy, J. R. Newbold, and P. J. Buttery. 1993. Effect of synchronizing the rate of dietary energy and nitrogen release on rumen fermentation and microbial protein synthesis in sheep. J. Agric. Sci. 120:251-263.

Tamminga, S., G. G. Brandsma, G.V. Duinkerken, A. M. v. Vuuren, and M. C. Blok. 2007. Protein evaluation for ruminants: The DVE/OEB 2007-system. CVB documentation report 53.

Tamminga, S., and J. O. Goelema. 1995. The significance of rate and site of starch digestion in ruminants. Carbohydrates in feeds for ruminants. Proc. SCI, London, UK.

Tamminga, S., W. M. Van Straalen, A. P. J. Subnel, R. G. M. Meijer, A. Steg, C. J. G. Wever, and M. C. Blok. 1994. The Dutch protein evaluation system: The DVE/OEB-system. Livest. Prod. Sci. 40:139-155.

Theodoridou, K., and P. Yu. 2013. Effect of processing conditions on the nutritive value of canola meal and presscake. Comparison of the yellow and brown-seeded canola meal with the brown-seeded canola presscake: Effect of processing conditions on the nutritive value of canola meal and canola presscake. J. Sci. Food Agric. 93:1986-1995.

Thomas, M., and A. F. B. van der Poel. 1996. Physical quality of pelleted animal feed 1. Criteria for pellet quality. Anim. Feed Sci. Technol. 61:89-112.

Thomas, M., D. J. Van Zuilichem, and A. F. B. Van der Poel. 1997. Physical quality of pelleted animal feed. 2. Contribution of processes and its conditions. Anim. Feed Sci. Technol. 64:173-192.
Van der Poel, A. F. B., M. W. A. Verstegen, and S. Tarnminga. 1995. Chemical, physical and nutritional effects of feed processing technology. Page 266 in 16th Western Nutrition Conference, Saskatoon, SK, Canada.

Van Soest, P. J., J. B. Robertson, and B. A. Lewis. 1991. Carbohydrate methodology, metabolism and nutritional implications in dairy cattle. Methods for dietary fiber, neutral detergent fiber and nonstarch polysaccharides in relation to animal nutrition. J. Dairy Sci. 74:3583-3597.

Voragen, A. G. J., H. Gruppen, G. J. P. Marsman, and A. J. Mul 1995. Effect of some manufacturing technologies on chemical, physical and nutritional properties of feed. Pages 93-126 in Recent Advances in Animal Nutrition: University of Nottingham Feed Manufacturers Conference 1995. P. C. Garnsworthy and D. J. A Cole ed. Nottingham University Press, Nottingham, UK.

Yan, X., N. A. Khan, F. Zhang, L. Yang, and P. Yu. 2014. Microwave irradiation induced changes in protein molecular structures of barley grains: Relationship to changes in protein chemical profile, protein subfractions, and digestion in dairy cows. J. Agric. Food Chem. 62:6546-6555

Yang, L., D. A. Christensen, J. J. McKinnon, A. D. Beattie, and P. Yu. 2013. Effect of altered carbohydrate traits in hullless barley (Hordeum vulgare $L$.) on nutrient profiles and availability and nitrogen to energy synchronization. J. Cereal Sci. 58:182-190.

Yu, P., D. A. Christensen, and J. J. McKinnon. 2003. Comparison of the National Research Council-2001 model with the Dutch system (DVE/OEB) in the prediction of nutrient supply to dairy cows from forages. J. Dairy Sci. 86:2178-2192.

Yu, P., J. O. Goelema, and S. Tamminga. 2000. Using the DVE/ OEB model to determine optimal conditions of pressure toasting on horse beans (Vicia faba) for the dairy feed industry. Anim. Feed Sci. Technol. 86:165-176.

Yu, P., K. Hart, and L. Du. 2009. An investigation of carbohydrate and protein degradation ratios, nitrogen to energy synchronization, and hourly effective rumen digestion of barley: effect of variety and growth year. J. Anim. Physiol. Anim. Nutr. (Berl.) 93:555-567. 